\title{
Synergistic effects of $A P O E$ and sex on the gut microbiome of young EFAD transgenic mice
}

Juan Maldonado Weng ${ }^{1}$, Ishita Parikh², Ankur Naqib33, Jason York', Stefan J. Green³, Steven Estus ${ }^{2}$ and Mary Jo LaDu ${ }^{1 *}$ (D)

\begin{abstract}
Background: Alzheimer's disease (AD) is a fatal neurodegenerative disease. APOE4 is the greatest genetic risk factor for $\mathrm{AD}$, increasing risk up to 15-fold compared to the common APOE3. Importantly, female (P) APOE4 carriers have a greater risk for developing $A D$ and an increased rate of cognitive decline compared to male (đ) APOE4 carriers. While recent evidence demonstrates that $A D, A P O E$ genotype, and sex affect the gut microbiome (GM), how APOE genotype and sex interact to affect the GM in $A D$ remains unknown.

Methods: This study analyzes the GM of 4-month (4 M) $\hat{\partial}$ and $q$ E3FAD and E4FAD mice, transgenic mice that overproduce amyloid- $\beta 42$ (A 342 ) and express human $A P O E 3^{+/+}$or $A P O E 4^{+/+}$. Fecal microbiotas were analyzed using high-throughput sequencing of $16 \mathrm{~S}$ ribosomal RNA gene amplicons and clustered into operational taxonomic units (OTU). Microbial diversity of the EFAD GM was compared across APOE, sex and stratified by APOE + sex, resulting in

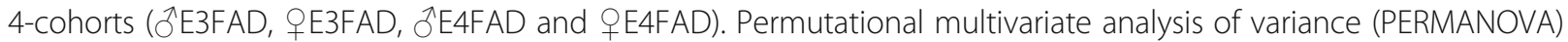
evaluated differences in bacterial communities between cohorts and the effects of $A P O E+$ sex. Mann-Whitney tests and machine-learning algorithms identified differentially abundant taxa associated with APOE + sex.

Results: Significant differences in the EFAD GM were associated with APOE genotype and sex. Stratification by $A P O E+$ sex revealed that APOE-associated differences were exhibited in ${ }^{\top} E F A D$ and PEFAD mice, and sexassociated differences were exhibited in E3FAD and E4FAD mice. Specifically, the relative abundance of bacteria from the genera Prevotella and Ruminococcus was significantly higher in o+E4FAD compared to EE3FAD, while the relative abundance of Sutterella was significantly higher in ${ }^{\lambda} E 4 F A D$ compared to ${ }^{\lambda} E 3 F A D$. Based on 29 OTUs identified by the machine-learning algorithms, heatmap analysis revealed significant clustering of PE4FAD separate from other cohorts.

Conclusions: The results demonstrate that the 4 M EFAD GM is modulated by APOE + sex. Importantly, the effect of APOE4 on the EFAD GM is modulated by sex, a pattern similar to the greater AD pathology associated with OE $4 F A D$. While this study demonstrates the importance of interactive effects of $A P O E+$ sex on the GM in young AD transgenic mice, changes associated with the development of pathology remain to be defined.
\end{abstract}

Keywords: Alzheimer's disease, Gut microbiome, APOE genotype, Sex

\footnotetext{
* Correspondence: mladu@uic.edu

'Department of Anatomy and Cell Biology, College of Medicine, University of

Illinois at Chicago, Chicago, IL 60612, USA

Full list of author information is available at the end of the article
}

(c) The Author(s). 2019 Open Access This article is distributed under the terms of the Creative Commons Attribution 4.0 International License (http://creativecommons.org/licenses/by/4.0/), which permits unrestricted use, distribution, and reproduction in any medium, provided you give appropriate credit to the original author(s) and the source, provide a link to the Creative Commons license, and indicate if changes were made. The Creative Commons Public Domain Dedication waiver (http://creativecommons.org/publicdomain/zero/1.0/) applies to the data made available in this article, unless otherwise stated. 


\section{Background}

The gut microbiome (GM), the collective genome of gastrointestinal bacteria, is an integral component of human physiology [1-5]. Recent studies link dysbiotic GM profiles with neurological disorders, with multiple sclerosis the first identified [6-12]. While subsequent studies have linked dysbiosis with Alzheimer's disease (AD) pathology [13-22], the effects of AD risk factors, specifically $A P O E$ genotype, sex and their interaction, on the GM remain unclear.

The APOE4 genotype is the greatest genetic risk factor for $\mathrm{AD}$, increasing risk up to 15 -fold compared to the more common APOE3 genotype [23, 24]. Apolipoprotein $\mathrm{E}$ (apoE) is a member of the apolipoprotein family, the protein components of lipoproteins. Both humans and AD transgenic (-Tg) mice with APOE4 exhibit an increase in amyloid- $\beta$ (A $\beta)$ peptide accumulation, both as amyloid plaques, a hallmark of the disease, and small soluble aggregates. Thus, one explanation for the APOE4-associated $\mathrm{AD}$ risk is a loss of function in $\mathrm{A} \beta$ clearance. Tran and colleagues demonstrated significant differences between the GM of human APOE3 and $A P O E 4$ carriers, as well as differences between the GM of $A P O E 3$ and APOE4 targeted replacement (-TR) mice [25]. These differences were attributed to a loss of apoE4 function in lipid homeostasis, as APOE4 is associated with higher levels of cholesterol, triglycerides and lowdensity lipoproteins compared to APOE3 [26-29], changes that significantly affect the GM [30-37]. Sex is another risk factor for AD as females () exhibit almost two-fold greater lifetime AD risk compared to males ( $\widehat{\jmath})$ [38]. Additionally, sex plays an important role in the GM as the bacterial composition and metabolic function differ significantly between $\delta$ and $q$ [37, 39-46]. Importantly, $\triangle A P O E 4$ carriers have a greater lifetime risk for developing $\mathrm{AD}$, an increased rate of cognitive decline and an accelerated accumulation of $\mathrm{A} \beta$ compared to $\checkmark$ APOE4 carriers [47-61]. While the underlying mechanism is unclear, evidence suggests this interaction modulates the GM.

EFAD-Tg mice [62] overexpress $A \beta 42$ via five familial $\mathrm{AD}$ (FAD) mutations [63] and express $\mathrm{h}-A P O E 3$ or $A P O E 4$, allowing for the study of the interaction among $\mathrm{AD}$ risk factors [64-66]. EFAD mice expressing the $\mathrm{APOE}^{+/+}$genotype (E4FAD), compared to E3FAD mice, exhibit increased behavioral deficits, $A \beta$ deposition and neuroinflammation. Importantly, these differences are reproduced in $q$ vs ${ }^{\wedge} E F A D$ mice, resulting in 4 pathologically-distinct cohorts when the EFAD mice are stratified by $A P O E+\operatorname{sex}(q \mathrm{E} 4 \mathrm{FAD}>\widehat{ } \mathrm{E} 4 \mathrm{FAD}=$ q E3FAD > ${ }^{\lambda}$ E3FAD), a phenotype that develops with age $[65,66]$. For this study, we focused on $4 \mathrm{M}$ EFAD mice to evaluate the interactive effects of $A P O E+$ sex on the $\mathrm{GM}$ at an age prior to, or early in, the development of pathology. Microbial analysis of fecal samples demonstrated that $A P O E+$ sex have a significant effect on the $\mathrm{GM}$ at various taxonomic levels.

\section{Methods}

\section{Mouse model}

As previously described, the EFAD $\left(5 \mathrm{xFAD}^{+/-} / \mathrm{APOE}^{+/+}\right)$ mice are homozygous for APOE2, APOE3, or APOE4 and heterozygous for the $5 \mathrm{x}$ familial $\mathrm{AD}(5 \mathrm{xFAD})$ mutations [62, 63]. Although APOE2 is considered neuroprotective, $100 \%$ of $A P O E 2^{+/+}$mice have type III hyperlipoproteinemia, compared to only $15 \%$ of human $\varepsilon 2 / 2$ carriers [67-69]; thus, E2FAD mice were excluded from the current study. At $4 \mathrm{M}$, fecal samples were obtained from the 4 cohorts (9 JE3FAD, 8 J E4FAD, 19 QE3FAD, 12 F $4 F A D)$ by individually placing mice in clean disposable Styrofoam cups. Feces were flash frozen and stored at $-80^{\circ} \mathrm{C}$ until DNA isolation.

\section{Bacteria identification}

Fecal DNA was isolated using a PowerSoil DNA isolation kit (Mo Bio Laboratories) and DNA concentrations determined by UV absorbance (Nanodrop, ThermoFisher). The V4 variable region of $16 \mathrm{~S}$ ribosomal RNA gene was PCR-amplified using target-specific primers containing bar codes and linker sequences [70]. PCR reaction conditions included an initial denaturation step of $30 \mathrm{~s}$ (s) at $98^{\circ} \mathrm{C}$, followed by 28 cycles of $10 \mathrm{~s}$ at $98^{\circ} \mathrm{C}, 15$ $\mathrm{s}$ at $60^{\circ} \mathrm{C}, 30 \mathrm{~s}$ at $72{ }^{\circ} \mathrm{C}$, and a final elongation step of 7 min at $72{ }^{\circ} \mathrm{C}$. The PCR master mix (20 $\mu$ l volume) contained $100 \mathrm{ng}$ of DNA template, $0.5 \mu \mathrm{M}$ forward and reverse primers, Phusion Hot Start DNA polymerase and high-fidelity buffer (New England Biolabs), dNTPs and sterile water. Results were checked by polyacrylamide gel electrophoresis and samples pooled in equimolar ratio. The samples were sequenced on an Illumina MiSeq sequencer at the University of Kentucky Advanced Genetic Technologies Center, with sequence merging, trimming, chimera removal, clustering and annotation performed using the software package QIIME [71]. The Greengenes database was implemented for Operational Taxonomic Unit (OTU) annotation at a threshold of $97 \%$ sequence similarity [72]. To avoid effects of uneven sequencing depth [73], datasets were rarified to 3000 sequences/ sample prior to analysis. For statistical analyses, OTUs with a frequency below $0.1 \%$ across the dataset were removed [71].

\section{Data analysis}

The Shannon $\mathrm{H}$ a-diversity index was used to assess bacterial richness and evenness. The interaction between $A P O E+$ sex in $\alpha$-diversity measures was evaluated using a mixed effects model, similar to a two-way analysis of variance (ANOVA), that analyzes repeated measures 
with missing values. This analysis was performed in the software package GraphPad Prism (version 8.2.0). For $\beta$ diversity, permutational ANOVA (PERMANOVA) was used to compare microbial community structure within and among the EFAD cohorts based on Bray-Curtis dissimilarity $[74,75]$. Pair-wise PERMANOVA was used to assess the effect of the interaction among universal biological variables on the microbiome composition [76]. Principal coordinate analysis plots (PCoA; Bray-Curtis distances) with $95 \%$ confidence ellipses were used to visualize microbial communities [75, 77, 78]. The MannWhitney U (MWU) test under the Monte Carlo simulation, corrected with Benjamini-Hochberg False Discovery Rate $(p<0.05)$, was used to identify differentially abundant taxa associated with $A P O E+$ sex at the taxonomic level of genus. The Random Forest based Boruta algorithm was used to determine OTUs significant in distinguishing samples by $A P O E$ + sex compared to randomly generated probes or "shadow scores" [79]. Heatmaps were generated using the R package, "pheatmaps", calculating the Euclidean distance among cohorts.

\section{Results and discussion}

Mouse fecal microbial community structure was analyzed using high-throughput sequencing of $16 \mathrm{~S}$ rRNA gene amplicons, followed by sequence clustering ( $97 \%$ similarity) into a total of 2063 OTUs. No significant difference in $\alpha$-diversity (Shannon $\mathrm{H}$ index) was observed between E3FAD and E4FAD mice ( $p=0.975$; Additional file 1: Figure S1A) or between ${ }^{\lambda} \mathrm{EFAD}$ and PEFAD ( $p=0.949$; Additional file 1: Figure S1B). In comparing across cohorts stratified by $A P O E+$ sex, Shannon $\mathrm{H}$ indices were significantly higher in ${ }^{\lambda} \mathrm{E} 4 \mathrm{FAD}$

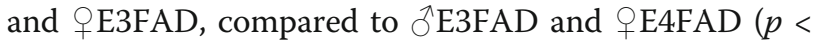
0.05; Additional file 1: Figure S1C). Additionally, the interaction of $A P O E+$ sex significantly modulated $\alpha-$ diversity measures $(p<0.05$; Additional file 1: Figure $\mathrm{S} 1 \mathrm{C})$, suggesting that analyses by $A P O E$ genotype or sex alone will mask effects on microbial community structure.

Differences in microbial community structure between EFAD cohorts ( $\beta$-diversity) were examined with PERMANOVA (Additional file 3: Table S1) and visualized with PCoA plots (Fig. 1). At the taxonomic level of OTU, significant differences in microbial communities were observed between E3FAD and E4FAD mice $(p<$ 0.05; Fig. 1a) and between $\widehat{D E F A D}$ and $्$ EFAD mice $(p<0.05$; Fig. 1b). Differences associated with $A P O E$ genotype were also exhibited in the taxonomic levels of Family and Genus (Additional file 3: Table S1A), suggesting that $A P O E$ genotype is an important modulator of the GM, consistent with findings in $A P O E-T R$ mice [25]. Importantly, the interaction between $A P O E+$ sex significantly modulated the GM across taxonomic levels of Family, Genus and OTU ( $p<0.05$; Additional file 3: Table S1A). Comparisons at the OTU level among samples stratified by $A P O E+$ sex demonstrated significant differences between $\widehat{ } \mathrm{E} 4 \mathrm{FAD}$ and $\widehat{ } \mathrm{E} 3 \mathrm{FAD}$ mice $(p<$ 0.05; Fig. 1c), and between + E4FAD and + E3FAD mice ( $p<0.05$; Fig. 1c), indicating that the effect of $A P O E$ genotype is consistent across sex. Furthermore, significant differences associated with sex were observed be-

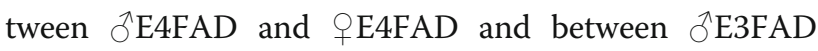
and 9 E3FAD $(p<0.05$; Fig. 1c). These data demonstrate that the $A P O E$ genotype interacts with sex, leading to sex differentiation in E3FAD and E4FAD mice. While a recent paper by Dodiya and colleagues demonstrated no sex effect on $\alpha$ - or $\beta$-diversity in FAD-Tg mice that express mouse $A P O E$ [80], the current findings may suggest that the sex effect is specific to carriers of human $A P O E$. This mirrors the synergistic effects of $q$ sex and $A P O E 4$ genotype on $\mathrm{AD}$ risk in humans, greatest in 9 APOE4 > § APOE4 [47-50].

A taxon-by-taxon analysis at the genus level was performed to identify microbial genera significantly different between cohorts. The relative abundance of the genera Prevotella, Ruminonoccous and Sutterella were significantly higher in E3FAD mice compared to E4FAD mice, while the relative abundance of Anaeroplasma was significantly lower (Fig. 2a). Interestingly, FAD-Tg mice also exhibited significantly higher relative abundance of Anaeroplasma compared to wild-type mice [81, 82], suggesting that Anaeroplasma may have a role in $\mathrm{AD}$ pathology. Tran and colleagues demonstrated that APOE4TR mice exhibit greater relative abundance of bacteria from the genera Mucispirillum, Desulfovibrio, Butyricicoccus and lower relative abundance of Bacteroides, Alistipes, Johnsonella compared to APOE3-TR mice [25]. Thus, our results together suggest that the effects of $A P O E$ genotype on the GM is modulated by $\mathrm{AD}$ pathology. Additionally, Org and colleagues determined that Allobaculum, Anaeroplasma and Erwinia are the most abundant genera in ${ }^{7}$ mice relative to $q$ mice [83]. Similarly, ${ }^{\lambda} E F A D$ exhibited a significantly greater relative abundance of Allobaculum compared to PEFAD (Fig. 2b). Comparing the stratified cohorts, the fecal microbiota of ${ }^{\lambda}$ E4FAD mice had lower relative abundance of Sutterella and Lactobacillus compared to ऽE3FAD. +E4FAD mice had lower relative abundance of Prevotella and Ruminococcus compared to $9 \mathrm{E} 3 \mathrm{FAD}$ (Fig. 2c). Similarly, these differences are significant at the OTU level (Additional file 4: Table S2). Therefore, the results suggest that the effect of $A P O E$ genotype on differentially abundant bacteria is modulated by sex, as specific genera and OTUs are significantly different in males or females.

Compared to 9 E3FAD mice, 9 E4FAD mice exhibited a lower relative abundance of bacterial genera associated 
A. APOE

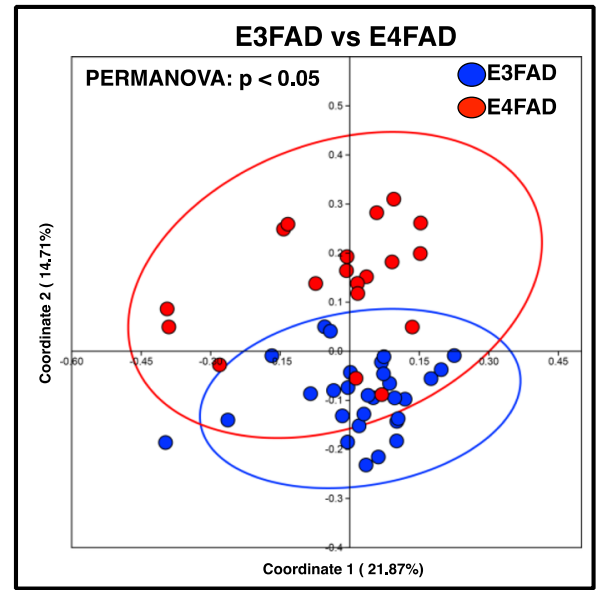

C. $A P O E+\operatorname{Sex}$
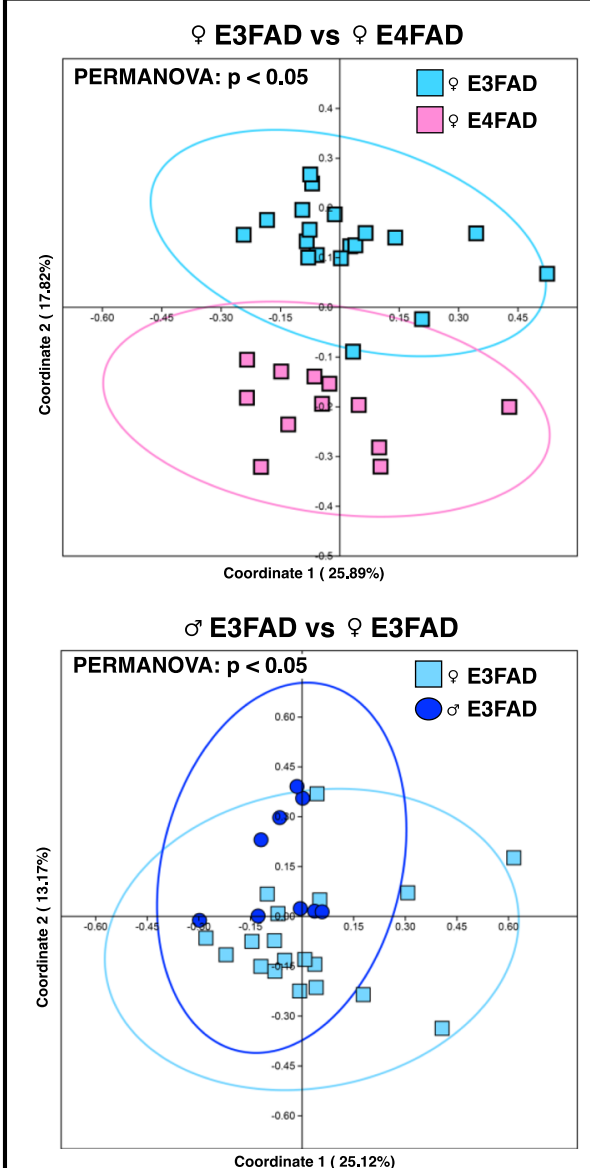

B. Sex

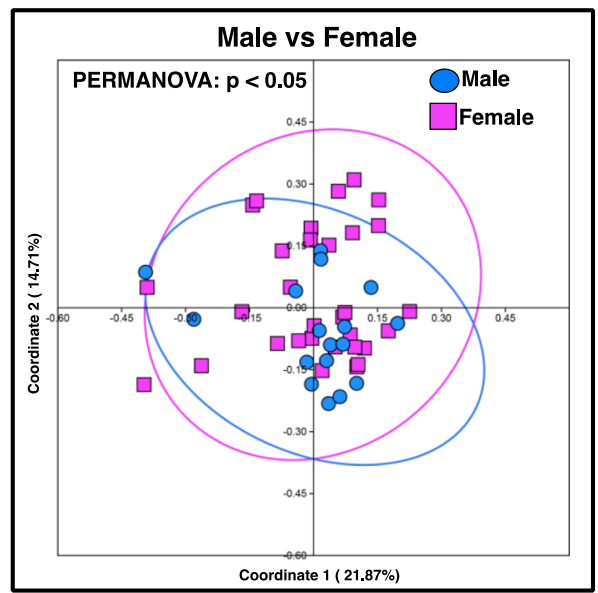

O E3FAD vs Ơ E4FAD

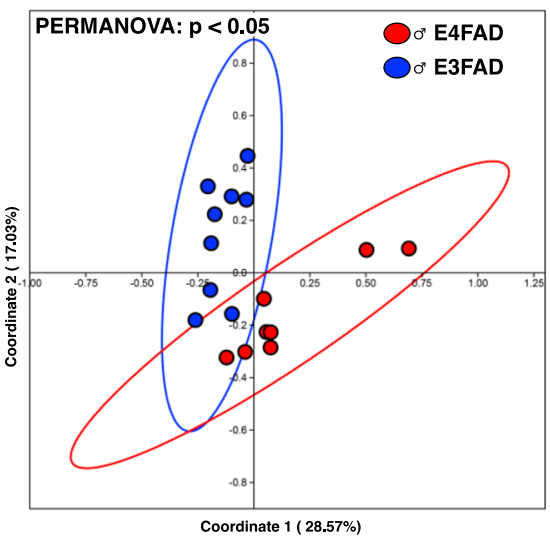

ơ E4FAD vs 9 E4FAD

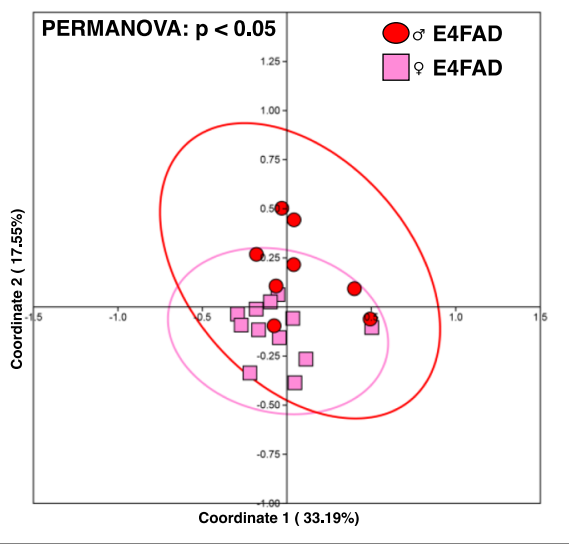

Fig. 1 Differences in microbial community between EFAD mice stratified by APOE, sex and APOE + sex. Analysis of $\beta$-diversity associated with (a) $A P O E$, (b) sex and (c) APOE + sex in the GM of 4 M EFAD mice. PCOA plots with 95\% confidence ellipses were generated based on the Bray-Curtis dissimilarity. Significant differences between cohorts were determined by PERMANOVA, with significance (bold) defined by $p<0.05$. Additional file 1: Table S1 contains the complete PERMANOVA dataset

with short chain fatty acid (SCFA) production, including Prevotella and Ruminococcus [84-89]. The GM is crucial for the production of SCFAs that, while the underlying mechanism is not completely understood, serve as energy sources for intestinal epithelial cells, regulators of plasma lipid levels, and modulators of immune cells 


\section{A. APOE}
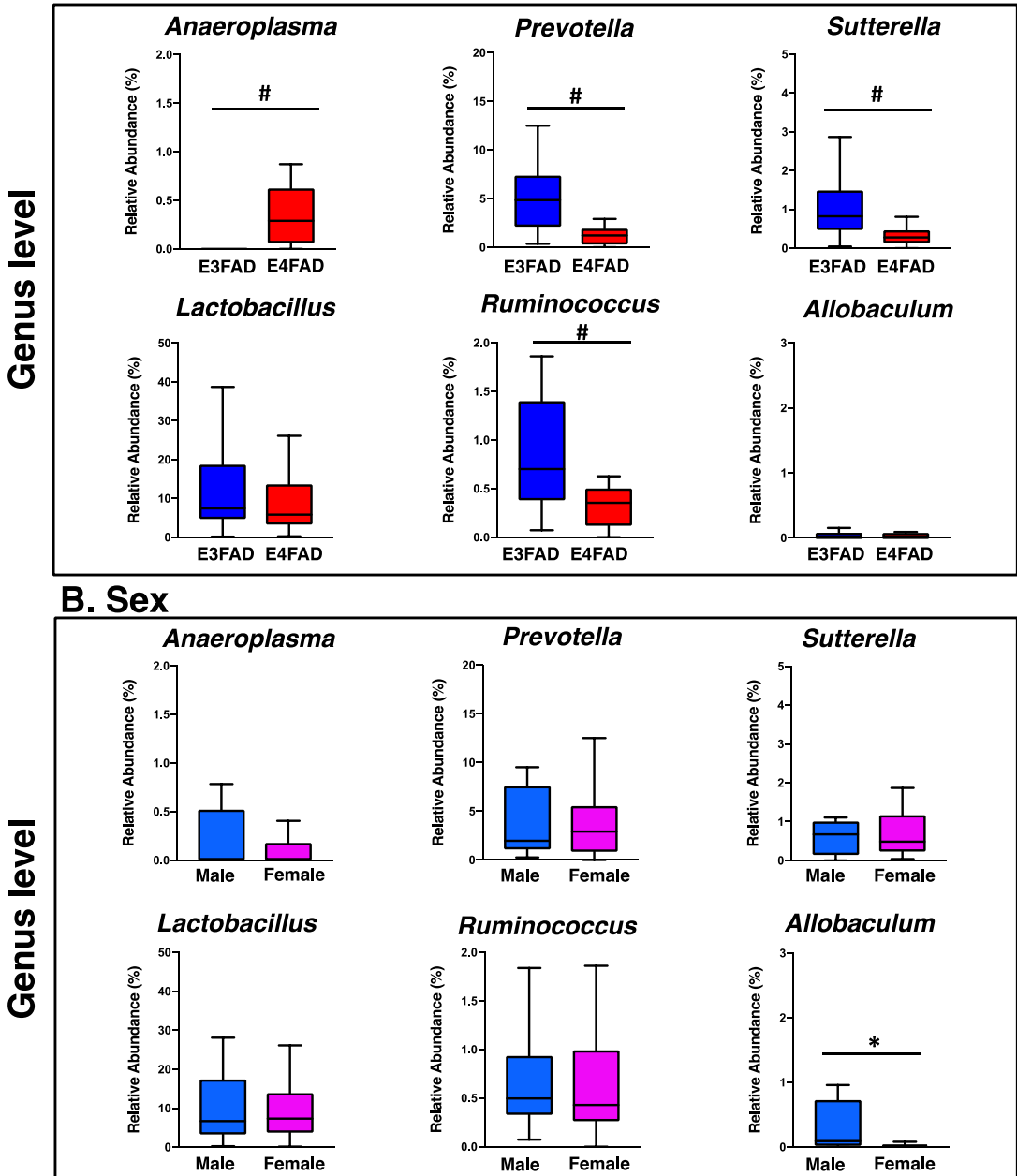

\section{C. $A P O E+$ Sex}

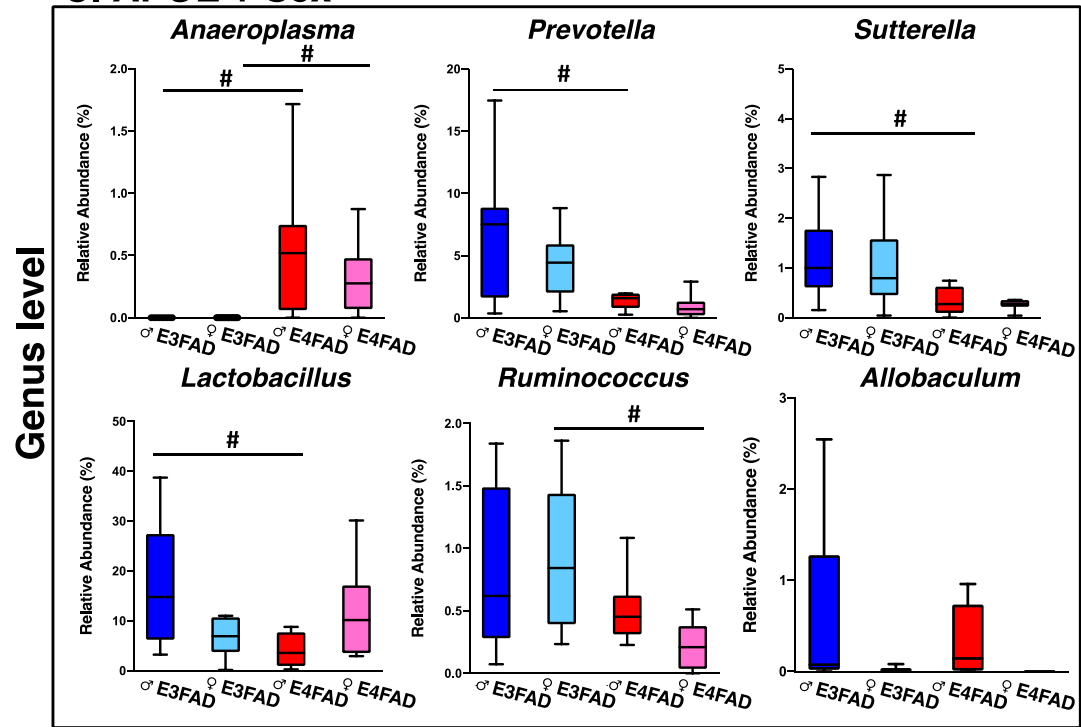

Fig. 2 (See legend on next page.) 
(See figure on previous page.)

Fig. 2 Relative abundance of bacterial genera in EFAD mice stratified by $A P O E$, sex, APOE + sex. Significantly different relative abundance of genus-level bacterial taxa associated with (a) $A P O E$, (b) sex and (c) $A P O E+$ sex, identified by Mann-Whitney $U$ test with a Monte Carlo Simulation corrected for false discovery rate ( ${ }^{*} p<0.05$ vs sex; $\# p<0.05$ vs genotype). Tukey plots show the median and interquartile range, with outliers removed from the graph. Significantly different relative abundance of unclassified genera and taxa from other taxonomic levels are found in the Additional file 4: Table S2.

[90-95]. The current results suggest a metabolic dysfunction in the PE4FAD GM. However, metabolomic and metagenomic analyses will be required to interpret accurately the interactive effects of $A P O E+$ sex on the metabolic function of the EFAD GM.

The Boruta algorithm identified 29 OTUs significant in distinguishing EFAD samples by $A P O E$ + sex (Additional file 2: Figure S2). These 29 bacterial OTUs were annotated at varying taxonomic levels, including the genera Prevotella, Lactobacillus, Allobaculum, Anaeroplasma, and Sutterella, consistent with the results of differentially abundant bacteria (Fig. 2). Based on the abundance of these 29 OTUs, a hierarchical heatmap demonstrates that EFAD samples clustered by $A P O E+$ sex (Fig. 3). Clustering of PE4FAD samples is further demonstration that the murine GM is affected by a specific interaction between $A P O E 4$ genotype and $\odot$ sex, consistent with human $O A P O E 4$ carriers exhibiting greater AD risk compared to ${ }^{\uparrow} A P O E 4$ carriers [47-50].

\section{Conclusions}

This short report demonstrates: 1) the EFAD GM is modulated by $A P O E+\operatorname{sex}, 2)$ the synergistic effects of q sex and APOE4 genotype yield a specific GM profile in QE4FAD mice, and 3) clustering samples by only $A P O E$ genotype or sex masks the interactive effects of $A P O E+$ sex on the EFAD GM. Notably, these findings are consistent with $\mathrm{AD}$ readouts from EFAD mice varying in severity of pathology by $A P O E+$ sex, including behavioral deficits, $A \beta$ deposition and neuroinflammation greatest in 으4FAD $>\lambda \mathrm{E} 4 \mathrm{FAD}=$ क $\mathrm{E} 3 \mathrm{FAD}>\lambda \mathrm{E} 3 \mathrm{FAD}[65,66]$. Therefore, the GM would potentially serve as an $\mathrm{AD}$

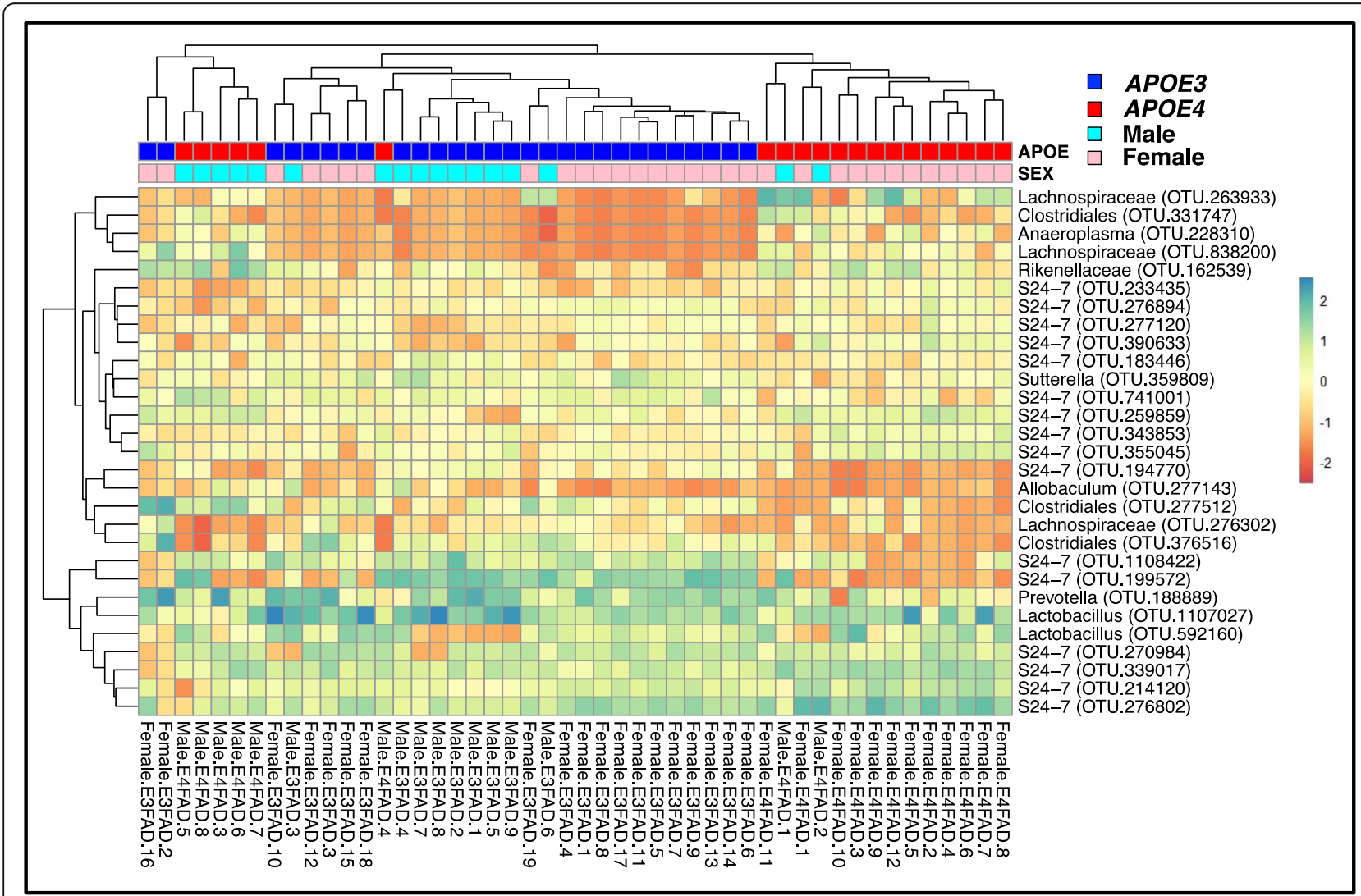

Fig. 3 Two-way clustered heatmap of microbial OTUs from EFAD mice stratified by APOE + sex. Heatmap generated with hierarchical clustering (Euclidean distance, complete linkage) based on bacterial OTUs identified by Boruta, a Random Forest based machine learning algorithm (Additional file 2: Fig. S2) 
readout, reflecting the interaction between $A P O E$ + sex. Although the use of $16 \mathrm{~S}$ rRNA sequencing has more limited taxonomic resolution than shotgun metagenome sequencing [96], 16S rRNA sequencing is sufficiently robust to identify significant effects on the GM. This study demonstrates the importance of stratifying the EFAD population by $A P O E+$ sex to better understand the relationship between $\mathrm{AD}$ and the GM. Future studies will examine the composition and metabolic function of the GM throughout the development of EFAD pathology through the use of metagenomic and metabolomic analyses. In conclusion, the interactive effects of $A P O E+$ sex on $\mathrm{AD}$ play an important role in modulating the GM composition, and the current report is the first step in identifying and understanding these effects.

\section{Supplementary information}

Supplementary information accompanies this paper at https://doi.org/10. 1186/s13024-019-0352-2.

Additional file 1: Figure S1. Analysis of a-diversity of EFAD mice stratified by $A P O E$, sex, APOE + sex. Based on bacterial evenness and richness, Shannon $\mathrm{H}$ index scores were generated and compared across EFAD mice stratified by (A) $A P O E$, (B) sex and (C) $A P O E$ + sex with MannWhitney $U$ test ( ${ }^{*} p<0.05$ vs sex; $\# p<0.05$ vs genotype). A mixed-model analysis was used to evaluate the interactive effects of $A P O E+$ sex on richness, evenness and a-diversity (I $p<0.05$ vs $A P O E+$ sex).

Additional file 2: Figure S2. Boruta-identified bacterial OTUs from EFAD mice stratified by APOE + sex. Implementing the R package "randomForest", Boruta is a feature-selection algorithm that determined the OTUs that were significant in distinguish samples by APOE + sex compared to randomly generated probes ("shadow scores" in blue). Significance is defined by a $z$-score > max shadow $z$-score (green; listed in the table). OTUs with a z-score that trends towards significance are labeled in yellow.

Additional file 3: Table S1. Permutational multivariate analysis of variance (PERMANOVA) of EFAD mice stratified by APOE, sex, APOE + sex. (A) PERMANOVA was used to assess the effect of the interaction between universal biological variables on the microbiome composition at various taxonomic levels. P-values were obtained using 9999 permutations under a reduced model. Pseudo- $F$ ratio is defined by the difference between cohorts over the difference within each cohort and the degrees of freedom. Each term is contributing a fixed component to the overall model. Estimated sizes of components of variation are multivariate analogs to the classical ANOVA unbiased estimators. Significance (bold) is defined by a $p<0.05$. (B) As the interaction between $A P O E+$ sex is significant, pair-wise PERMANOVAs at the OTU level evaluated the effects of APOE on $\beta$-diversity within ${ }^{\lambda} E F A D$ and $O E F A D$ mice, and the effects of sex in E3FAD and E4FAD. Significance (bold) is defined by a $p<0.05$.

Additional file 4: Table S2. Results of Mann-Whitney $U$ tests at specific taxonomic levels in EFAD mice. Significantly different relative abundance of bacterial genera associated with $A P O E$, sex, and $A P O E$ + sex, identified by Mann-Whitney $U$ under the Monte Carlo Simulation corrected for false discovery rate $(p<0.05)$ at the levels of Phylum, Class, Order, Family, Genus and OTU.

\section{Abbreviations}

AD: Alzheimer's disease; apoE: Apolipoprotein E; Aß: Amyloid- $\beta$; FAD: Familial AD; GM: Gut microbiome; MWU: Mann-Whitney U; OTU: Operational taxonomic units; Perm: Permutation; PERMANOVA: Permutational multivariate analysis of variance; SCFA: Short chain fatty acid; Tg: Transgenic

\section{Acknowledgements}

Not applicable.

\section{Authors' contributions}

$\mathrm{ML}$ and JMW analyzed the data and wrote the manuscript, IP and SE purified DNA and performed PCR, JMW and SJG performed statistical analyses, JY bred the mice, SJG and SE contributed to data analysis and manuscript editing. All authors read and approved the final manuscript.

\section{Funding}

The authors acknowledge funding from the NIH (R56-AG057589 and P01AG030128) and the BrightFocus Foundation (A2014210S) to the Estus lab. The LaDu lab funding includes funds from NIH/NIA (R01 AG058068, R01 AG057008), institutional funds from the College of Medicine at the University of Illinois, Chicago, and philanthropic contributions. JMW was supported by an administrative supplement to R01 AG057008 and by the NSF Bridge to the Doctorate Fellowship.

\section{Availability of data and materials}

The datasets used and/or analyzed during the current study are available from the corresponding author on reasonable request. Raw sequence data files were submitted in the Sequence Read Archive (SRA) of the National Center for Biotechnology Information (NCBI). The BioProject identifier of the samples is PRJNA556445.

\section{Ethics approval}

Animal studies were performed in compliance with IACUC (Institutional Animal Care and Use Committee) at University of Illinois-Chicago.

\section{Consent for publication}

All authors read and approved the final manuscript.

\section{Competing interests}

The authors declare that they have no competing interests.

\section{Author details}

'Department of Anatomy and Cell Biology, College of Medicine, University of Illinois at Chicago, Chicago, IL 60612, USA. ${ }^{2}$ Department of Physiology and Sanders-Brown Center on Aging, University of Kentucky, Lexington, KY, USA.

${ }^{3}$ Research Resources Center, University of Illinois at Chicago, Chicago, IL, USA.

Received: 15 October 2019 Accepted: 11 December 2019

Published online: 20 December 2019

\section{References}

1. Laukens D, Brinkman BM, Raes J, De Vos M, Vandenabeele P. Heterogeneity of the gut microbiome in mice: guidelines for optimizing experimental design. FEMS Microbiol Rev. 2016:40(1):117-32.

2. Ursell LK, Metcalf JL, Parfrey LW, Knight R. Defining the human microbiome. Nutr Rev. 2012;70(Suppl 1):S38-44.

3. Collins $S M$, Surette $M$, Bercik $P$. The interplay between the intestinal microbiota and the brain. Nat Rev Microbiol. 2012;10(11):735-42.

4. Clarke G, Stilling RM, Kennedy PJ, Stanton C, Cryan JF, Dinan TG. Minireview: gut microbiota: the neglected endocrine organ. Mol Endocrinol. 2014;28(8): 1221-38.

5. Lyte M, Cryan JF. Dealing with ability of the microbiota to influence the brain, and ultimately cognition and behavioral. Adv Exp Med Biol. 2014;817:ix-xi.

6. DuPont AW, DuPont HL. The intestinal microbiota and chronic disorders of the gut. Nat Rev Gastroenterol Hepatol. 2011;8(9):523-31.

7. Levy M, Kolodziejczyk AA, Thaiss CA, Elinav E. Dysbiosis and the immune system. Nat Rev Immunol. 2017;17(4):219-32.

8. Chen J, Chia N, Kalari KR, Yao JZ, Novotna M, Paz Soldan MM, et al. Multiple sclerosis patients have a distinct gut microbiota compared to healthy controls. Sci Rep. 2016;6:28484

9. Tremlett H, Fadrosh DW, Faruqi AA, Zhu F, Hart J, Roalstad S, et al. Gut microbiota in early pediatric multiple sclerosis: a case-control study. Eur J Neurol. 2016;23(8):1308-21.

10. Bhargava P, Mowry EM. Gut microbiome and multiple sclerosis. Curr Neurol Neurosci Rep. 2014;14(10):492.

11. Jangi S, Gandhi R, Cox LM, Li N, von Glehn F, Yan R, et al. Alterations of the human gut microbiome in multiple sclerosis. Nat Commun. 2016;7:12015.

12. Ochoa-Reparaz J, Magori K, Kasper LH. The chicken or the egg dilemma: intestinal dysbiosis in multiple sclerosis. Ann Transl Med. 2017;5(6):145. 
13. Vogt NM, Kerby RL, Dill-McFarland KA, Harding SJ, Merluzzi AP, Johnson SC, et al. Gut microbiome alterations in Alzheimer's disease. Sci Rep. 2017;7(1):13537.

14. Cattaneo A, Cattane N, Galluzzi S, Provasi S, Lopizzo N, Festari C, et al. Association of brain amyloidosis with pro-inflammatory gut bacterial taxa and peripheral inflammation markers in cognitively impaired elderly. Neurobiol Aging. 2017:49:60-8.

15. MahmoudianDehkordi S, Arnold M, Nho K, Ahmad S, Jia W, Xie G, et al. Altered bile acid profile associates with cognitive impairment in Alzheimer's disease-an emerging role for gut microbiome. Alzheimers Dement. 2019; 15(1):76-92.

16. Fox M, Knorr DA, Haptonstall KM. Alzheimer's disease and symbiotic microbiota: an evolutionary medicine perspective. Ann N Y Acad Sci. 2019;1449(1):3-24.

17. Jiang C, Li G, Huang P, Liu Z, Zhao B. The gut microbiota and Alzheimer's disease. J Alzheimers Dis. 2017;58(1):1-15.

18. Angelucci F, Cechova K, Amlerova J, Hort J. Antibiotics, gut microbiota, and Alzheimer's disease. J Neuroinflammation. 2019;16(1):108.

19. Garcez ML, Jacobs KR, Guillemin GJ. Microbiota alterations in Alzheimer's disease: involvement of the Kynurenine pathway and inflammation. Neurotox Res. 2019;36(2):424-36.

20. Zhuang ZQ, Shen LL, Li WW, Fu X, Zeng F, Gui L, et al. Gut microbiota is altered in patients with Alzheimer's disease. J Alzheimers Dis. 2018:63(4):1337-46.

21. Liu P, Wu L, Peng G, Han Y, Tang R, Ge J, et al. Altered microbiomes distinguish Alzheimer's disease from amnestic mild cognitive impairment and health in a Chinese cohort. Brain Behav Immun. 2019;80:633-43.

22. Li B, He Y, Ma J, Huang P, Du J, Cao L, et al. Mild cognitive impairment has similar alterations as Alzheimer's disease in gut microbiota. Alzheimers Dement. 2019;15(10):1357-66.

23. Reitz C, Mayeux R. Use of genetic variation as biomarkers for mild cognitive impairment and progression of mild cognitive impairment to dementia. J Alzheimers Dis. 2010;19(1):229-51.

24. Leoni $\mathrm{V}$. The effect of apolipoprotein $E$ (ApoE) genotype on biomarkers of amyloidogenesis, tau pathology and neurodegeneration in Alzheimer's disease. Clin Chem Lab Med. 2011;49(3):375-83.

25. Tran TT, Corsini S, Kellingray L, Hegarty C, Le Gall G, Narbad A, et al. APOE genotype influences the gut microbiome structure and function in humans and mice: relevance for Alzheimer's disease pathophysiology. FASEB J. 2019; 33(7):fj201900071R.

26. Weisgraber KH. Apolipoprotein E: structure-function relationships. Adv Protein Chem. 1994;45:249-302.

27. Davignon J, Gregg RE, Sing CF. Apolipoprotein E polymorphism and atherosclerosis. Arteriosclerosis. 1988;8(1):1-21.

28. de Knijff P, van den Maagdenberg AM, Frants RR, Havekes LM. Genetic heterogeneity of apolipoprotein $\mathrm{E}$ and its influence on plasma lipid and lipoprotein levels. Hum Mutat. 1994;4(3):178-94.

29. Dallongeville J, Lussier-Cacan S, Davignon J. Modulation of plasma triglyceride levels by apoE phenotype: a meta-analysis. J Lipid Res. 1992; 33(4):447-54.

30. Caparros-Martin JA, Lareu RR, Ramsay JP, Peplies J, Reen FJ, Headlam HA, et al. Statin therapy causes gut dysbiosis in mice through a PXR-dependent mechanism. Microbiome. 2017;5(1):95.

31. David LA, Maurice CF, Carmody RN, Gootenberg DB, Button JE, Wolfe BE, et al. Diet rapidly and reproducibly alters the human gut microbiome. Nature. 2014:505(7484):559-63.

32. Natividad JM, Lamas B, Pham HP, Michel ML, Rainteau D, Bridonneau C, et al. Bilophila wadsworthia aggravates high fat diet induced metabolic dysfunctions in mice. Nat Commun. 2018;9(1):2802.

33. Ussar S, Griffin NW, Bezy O, Fujisaka S, Vienberg S, Softic S, et al. Interactions between gut microbiota, host genetics and diet modulate the predisposition to obesity and metabolic syndrome. Cell Metab. 2015;22(3):516-30.

34. Cani PD, Delzenne NM. The role of the gut microbiota in energy metabolism and metabolic disease. Curr Pharm Des. 2009;15(13):1546-58.

35. Rebolledo C, Cuevas A, Zambrano T, Acuna JJ, Jorquera MA, Saavedra K, et al. Bacterial community profile of the gut microbiota differs between Hypercholesterolemic subjects and controls. Biomed Res Int. 2017;2017: 8127814.

36. Caesar R, Nygren H, Oresic M, Backhed F. Interaction between dietary lipids and gut microbiota regulates hepatic cholesterol metabolism. J Lipid Res. 2016;57(3):474-81.

37. Haro C, Rangel-Zuniga OA, Alcala-Diaz JF, Gomez-Delgado F, Perez-Martinez $P$, Delgado-Lista J, et al. Intestinal microbiota is influenced by gender and body mass index. PLoS One. 2016;11(5):e0154090.
38. Chene G, Beiser A, Au R, Preis SR, Wolf PA, Dufouil C, et al. Gender and incidence of dementia in the Framingham heart study from mid-adult life. Alzheimers Dement. 2015;11(3):310-20.

39. Dominianni C, Sinha R, Goedert JJ, Pei Z, Yang L, Hayes RB, et al. Sex, body mass index, and dietary fiber intake influence the human gut microbiome. PLoS One. 2015;10(4):e0124599.

40. Kim YS, Unno T, Kim BY, Park MS. Sex Differences in Gut Microbiota. World J Mens Health. 2019;38(1):48-60.

41. Flores R, Shi J, Fuhrman B, Xu X, Veenstra TD, Gail MH, et al. Fecal microbial determinants of fecal and systemic estrogens and estrogen metabolites: a cross-sectional study. J Transl Med. 2012;10:253.

42. Jasarevic E, Morrison KE, Bale TL. Sex differences in the gut microbiomebrain axis across the lifespan. Philos Trans R Soc Lond Ser B Biol Sci. 2016; 371(1688):20150122.

43. Yurkovetskiy L, Burrows M, Khan AA, Graham L, Volchkov P, Becker L, et al. Gender bias in autoimmunity is influenced by microbiota. Immunity. 2013; 39(2):400-12.

44. Baker JM, Al-Nakkash L, Herbst-Kralovetz MM. Estrogen-gut microbiome axis: physiological and clinical implications. Maturitas. 2017;103:45-53.

45. Chen KL, Madak-Erdogan Z. Estrogen and microbiota crosstalk: should we pay attention? Trends Endocrinol Metab. 2016;27(11):752-5.

46. Mueller S, Saunier K, Hanisch C, Norin E, Alm L, Midtvedt T, et al. Differences in fecal microbiota in different European study populations in relation to age, gender, and country: a cross-sectional study. Appl Environ Microbiol. 2006; 72(2):1027-33.

47. Farrer LA, Cupples LA, Haines JL. Hyman B, Kukull WA, Mayeux R, et al. effects of age, sex, and ethnicity on the association between apolipoprotein E genotype and Alzheimer disease. A meta-analysis. APOE and Alzheimer disease Meta analysis consortium. JAMA. 1997;278(16):1349-56.

48. Altmann A, Tian L, Henderson WW, Greicius MD. Alzheimer's disease neuroimaging initiative I. sex modifies the APOE-related risk of developing Alzheimer disease. Ann Neurol. 2014;75(4):563-73.

49. Bretsky PM, Buckwalter JG, Seeman TE, Miller CA, Poirier J, Schellenberg GD, et al. Evidence for an interaction between apolipoprotein E genotype, gender, and Alzheimer disease. Alzheimer Dis Assoc Disord. 1999;13(4):216-21.

50. Payami H, Zareparsi S, Montee KR, Sexton GJ, Kaye JA, Bird TD, et al. Gender difference in apolipoprotein E-associated risk for familial Alzheimer disease: a possible clue to the higher incidence of Alzheimer disease in women. Am J Hum Genet. 1996;58(4):803-11.

51. Breitner JC, Wyse BW, Anthony JC, Welsh-Bohmer KA, Steffens DC, Norton $M C$, et al. APOE-epsilon 4 count predicts age when prevalence of $A D$ increases, then declines: the Cache County study. Neurology. 1999;53(2): $321-31$

52. Martinez M, Campion D, Brice A, Hannequin D, Dubois B, Didierjean O, et al. Apolipoprotein E epsilon4 allele and familial aggregation of Alzheimer disease. Arch Neurol. 1998;55(6):810-6.

53. Andersen $\mathrm{K}$, Launer LJ, Dewey ME, Letenneur L, Ott A, Copeland JR, et al. Gender differences in the incidence of $A D$ and vascular dementia: the EURODEM studies. EURODEM Incidence Research Group. Neurology. 1999; 53(9):1992-7.

54. Molero AE, Pino-Ramirez G, Maestre GE. Modulation by age and gender of risk for Alzheimer's disease and vascular dementia associated with the apolipoprotein E-epsilon4 allele in Latin Americans: findings from the Maracaibo aging study. Neurosci Lett. 2001;307(1):5-8.

55. Corder EH, Ghebremedhin E, Taylor MG, Thal DR, Ohm TG, Braak H. The biphasic relationship between regional brain senile plaque and neurofibrillary tangle distributions: modification by age, sex, and APOE polymorphism. Ann N Y Acad Sci. 2004;1019:24-8.

56. Altmann A, Tian L, Henderson W, Greicius MD. Sex modifies the APOErelated risk of developing Alzheimer disease. Ann Neurol. 2014;75(4):563-73.

57. Hyman BT, Gomez-lsla T, Briggs M, Chung H, Nichols S, Kohout F, et al. Apolipoprotein $\mathrm{E}$ and cognitive change in an elderly population. Ann Neurol. 1996;40(1):55-66.

58. Mortensen EL, Hogh P. A gender difference in the association between APOE genotype and age-related cognitive decline. Neurology. 2001;57(1):89-95.

59. Holland D, Desikan RS, Dale AM, McEvoy LK. Alzheimer's disease neuroimaging I. higher rates of decline for women and apolipoprotein E epsilon4 carriers. AJNR Am J Neuroradiol. 2013;34(12):2287-93.

60. Fleisher A, Grundman M, Jack CR Jr, Petersen RC, Taylor C, Kim HT, et al. Sex, apolipoprotein E epsilon 4 status, and hippocampal volume in mild cognitive impairment. Arch Neurol. 2005;62(6):953-7. 
61. Jack CR Jr, Wiste HJ, Weigand SD, Knopman DS, Vemuri P, Mielke MM, et al. Age, sex, and APOE epsilon4 effects on memory, brain structure, and betaamyloid across the adult life span. JAMA Neurol. 2015;72(5):511-9.

62. Youmans KL, Tai LM, Nwabuisi-Heath E, Jungbauer L, Kanekiyo T, Gan M, et al. APOE4-specific changes in Abeta accumulation in a new transgenic mouse model of Alzheimer disease. J Biol Chem. 2012;287(50):41774-86.

63. Oakley H, Cole SL, Logan S, Maus E, Shao P, Craft J, et al. Intraneuronal betaamyloid aggregates, neurodegeneration, and neuron loss in transgenic mice with five familial Alzheimer's disease mutations: potential factors in amyloid plaque formation. J Neurosci. 2006;26(40):10129-40.

64. Tai LM, Ghura S, Koster KP, Liakaite V, Maienschein-Cline M, Kanabar P, et al. APOE-modulated Abeta-induced neuroinflammation in Alzheimer's disease: current landscape, novel data and future perspective. J Neurochem. 2015; 133(4):465-88

65. Tai LM, Balu D, Avila-Munoz E, Abdullah L, Thomas R, Collins N, et al. EFAD transgenic mice as a human APOE relevant preclinical model of Alzheimer's disease. J Lipid Res. 2017;58(9):1733-55.

66. Balu D, Karstens AJ, Loukenas E, Maldonado Weng J, Valencia-Olvera AC, LaDu MJ. The role of APOE in transgenic mouse models of AD. Neurosc Lett. 2019;134285. https://doi.org/10.1016/j.neulet.2019.134285. Available from: http://www.sciencedirect.com/science/article/pii/S030439401930357X

67. Sullivan PM, Mezdour H, Quarfordt SH, Maeda N. Type III hyperlipoproteinemia and spontaneous atherosclerosis in mice resulting from gene replacement of mouse Apoe with human Apoe*2. J Clin Invest. 1998;102(1):130-5

68. Corsetti JP, Sparks CE, Bakker SJL, Gruppen EG, Dullaart RPF. Roles of high apolipoprotein E blood levels and HDL in development of familial dysbetalipoproteinemia in epsilon2epsilon2 subjects. Clin Biochem. 2018;52: 67-72.

69. Koopal C, Marais AD, Westerink J, Visseren FL. Autosomal dominant familial dysbetalipoproteinemia: a pathophysiological framework and practical approach to diagnosis and therapy. J Clin Lipidol. 2017;11(1):12-23 e1.

70. Thompson LR, Sanders JG, McDonald D, Amir A, Ladau J, Locey KJ, et al. A communal catalogue reveals Earth's multiscale microbial diversity. Nature. 2017:551(7681):457-63.

71. Caporaso JG, Kuczynski J, Stombaugh J, Bittinger K, Bushman FD, Costello EK, et al. QIIME allows analysis of high-throughput community sequencing data. Nat Methods. 2010;7(5):335-6.

72. DeSantis TZ, Hugenholtz P, Larsen N, Rojas M, Brodie EL, Keller K, et al. Greengenes, a chimera-checked 16S rRNA gene database and workbench compatible with ARB. Appl Environ Microbiol. 2006;72(7):5069-72.

73. Gihring TM, Green SJ, Schadt CW. Massively parallel rRNA gene sequencing exacerbates the potential for biased community diversity comparisons due to variable library sizes. Environ Microbiol. 2012;14(2):285-90.

74. Clarke KR, Warwick RM. Change in Marine Communities: An Approach to Statistical Analysis and Interpretation. Plymouth: Primer-E Ltd; 2001.

75. Knight R, Vrbanac A, Taylor BC, Aksenov A, Callewaert C, Debelius J, et al. Best practices for analysing microbiomes. Nat Rev Microbiol. 2018;16(7):410-22.

76. Clarke KR. Non-parametric multivariate analyses of changes in community structure. Aust J Ecol. 1993;18(1):117-43.

77. Goodrich JK, Di Rienzi SC, Poole AC, Koren O, Walters WA, Caporaso JG, et al. Conducting a microbiome study. Cell. 2014;158(2):250-62.

78. Hammer $\varnothing$, Harper DAT, Ryan PD. Past: Paleontological Statistics Software Package for Education and Data Analysis. Palaeontol Electron. 2001;4(1):9.

79. Kursa MB, Rudnicki WR. Feature selection with the Boruta package. J Stat Softw. 2010;36(11):1-13.

80. Dodiya HB, Kuntz T, Shaik SM, Baufeld C, Leibowitz J, Zhang X, et al. Sexspecific effects of microbiome perturbations on cerebral Abeta amyloidosis and microglia phenotypes. J Exp Med. 2019:216(7):1542-60.

81. Harach T, Marungruang N, Duthilleul N, Cheatham V, Mc Coy KD, Frisoni G, et al. Reduction of Abeta amyloid pathology in APPPS1 transgenic mice in the absence of gut microbiota. Sci Rep. 2017;7:41802.

82. Sanguinetti E, Collado MC, Marrachelli VG, Monleon D, Selma-Royo M, Pardo-Tendero MM, et al. Microbiome-metabolome signatures in mice genetically prone to develop dementia, fed a normal or fatty diet. Sci Rep. 2018;8(1):4907

83. Org E, Mehrabian M, Parks BW, Shipkova P, Liu X, Drake TA, et al. Sex differences and hormonal effects on gut microbiota composition in mice. Gut Microbes. 2016;7(4):313-22.
84. Chen T, Long W, Zhang C, Liu S, Zhao L, Hamaker BR. Fiber-utilizing capacity varies in Prevotella- versus Bacteroides-dominated gut microbiota. Sci Rep. 2017;7(1):2594

85. Hiippala K, Kainulainen V, Kalliomaki M, Arkkila P, Satokari R. Mucosal prevalence and interactions with the epithelium indicate commensalism of Sutterella spp. Front Microbiol. 2016;7:1706.

86. La Reau AJ, Suen G. The Ruminococci: key symbionts of the gut ecosystem. J Microbiol. 2018:56(3):199-208.

87. De Filippis F, Pellegrini N, Vannini L, Jeffery IB, La Storia A, Laghi L, et al. High-level adherence to a Mediterranean diet beneficially impacts the gut microbiota and associated metabolome. Gut. 2016:65(11):1812-21.

88. Macfarlane GT, Macfarlane S. Bacteria, colonic fermentation, and gastrointestinal health. J AOAC Int. 2012;95(1):50-60

89. Kolmeder CA, Salojarvi J, Ritari J, de Been M, Raes J, Falony G, et al. Faecal Metaproteomic analysis reveals a personalized and stable functional microbiome and limited effects of a probiotic intervention in adults. PLoS One. 2016;11(4):e0153294.

90. den Besten G, van Eunen K, Groen AK, Venema K, Reijngoud DJ, Bakker BM. The role of short-chain fatty acids in the interplay between diet, gut microbiota, and host energy metabolism. J Lipid Res. 2013;54(9):2325-40.

91. Natarajan N, Pluznick JL. From microbe to man: the role of microbial short chain fatty acid metabolites in host cell biology. Am J Phys Cell Phys. 2014; 307(11):C979-85.

92. Holzer P, Farzi A, Hassan AM, Zenz G, Jacan A, Reichmann F. Visceral inflammation and immune activation stress the brain. Front Immunol. 2017; 8:1613.

93. Caballero-Villarraso J, Galvan A, Escribano BM, Tunez I. Interrelationships among gut microbiota and host: paradigms, role in neurodegenerative diseases and future prospects. CNS Neurol Disord Drug Targets. 2017;16(8): 945-64.

94. Yamada T, Takahashi D, Hase K. The diet-microbiota-metabolite axis regulates the host physiology. J Biochem. 2016;160(1):1-10

95. Dopkins N, Nagarkatti PS, Nagarkatti M. The role of gut microbiome and associated metabolome in the regulation of neuroinflammation in multiple sclerosis and its implications in attenuating chronic inflammation in other inflammatory and autoimmune disorders. Immunology. 2018;154(2):178-85.

96. Ranjan R, Rani A, Metwally A, McGee HS, Perkins DL. Analysis of the microbiome: advantages of whole genome shotgun versus $16 \mathrm{~S}$ amplicon sequencing. Biochem Biophys Res Commun. 2016;469(4):967-77.

\section{Publisher's Note}

Springer Nature remains neutral with regard to jurisdictional claims in published maps and institutional affiliations.

Ready to submit your research? Choose BMC and benefit from:

- fast, convenient online submission

- thorough peer review by experienced researchers in your field

- rapid publication on acceptance

- support for research data, including large and complex data types

- gold Open Access which fosters wider collaboration and increased citations

- maximum visibility for your research: over $100 \mathrm{M}$ website views per year

At $\mathrm{BMC}$, research is always in progress.

Learn more biomedcentral.com/submissions 